\title{
The Role of Stress During the COVID-19 Pandemic in the Future Career Anxiety of Final-Year Students
}

\author{
Rizka Rahmadani ${ }^{1}$ Riana Sahrani ${ }^{1 *}$ \\ ${ }^{1}$ Faculty of Psychology, Universitas Tarumanagara, West Jakarta 11440, Indonesia \\ "Corresponding author. Email: rianas@fpsi.untar.ac.id
}

\begin{abstract}
In the midst of the COVID-19 pandemic is very closely related to anxiety. From the growing number of unemployment the existence of economic recession, the high potential for job losses, and the decrease in wages caused by restrictions on activity, COVID-19 has reinforced the emergence of future career anxiety. Particularly, future career anxiety among final-year students needs to be researched, as students have to face pressures and adjustment as future workers in order to meet the needs of their life after graduating from college whilst facing the COVID-19 situation. Hence, the purpose of this study is to empirically test the role of stress during the COVID-19 pandemic against future career anxiety in final year students. This study is done through non-experimental quantitative method, which applied some measuring instruments, such as the COVID-19 Stress Scale (CSS) and Career Anxiety Scale. The data obtained in this study is analyzed through the SPSS application version 25 with simple linear regression analysis technique. The study subjects involved 432 final year students with an age range from 19 to 30 years old. The results indicate that stress during the COVID-19 pandemic has a significant role to play in the future career anxiety of final year students.
\end{abstract}

Keywords: Stress during the COVID-19 pandemic, future career anxiety, final-year student

\section{INTRODUCTION}

Since the emergence of COVID-19 outbreak in December 2019, the disease has spread rapidly throughout the world. On March 11, 2020, the World Health Organization (WHO) in its conference had officially announced the COVID-19 outbreak as a characteristic of a pandemic. In a pandemic like this, there is an interaction between external (threat) and internal (vulnerability) conditions that affect the risk of stress, that may debilitate an individual's mental health, which in turn may cause mental health problems [1]. This is in line with Jabri [2] who stated that the global effects of this virus are closely related to stress and anxiety. Common responses that occur in most people who are affected by the pandemic, either directly or indirectly, include fear of falling ill, dying, contracting the virus, losing their job, feeling helpless, bored, lonely, and depressed amidst isolation [3]. The effects of repeated dissemination of information and exposure to news about these extreme COVID-19 events can potentially increase the risk of general psychological disorders. The effect generally starts with a sense of discomfort, and from this discomfort can be a stressor for the individual [4] [5]. Individuals who are quarantined or isolated will spend days to weeks at home with social limitations to others, which can cause stress to the individual. During this period, the source of stress comes from decreased activity, sensory stimulation, social involvement, and financial pressure due to inability to work [6]. This is related to a research conducted by Sood [7] that quarantine can cause significant psychological disorders such as post-traumatic stress disorder, panic disorder, depression, anxiety, and behavioral disorders. In Indonesia, based on a survey report from the Indonesian Psychiatric Association [8] conducted through its online website, out of 1,305 people, $64.3 \%$ experienced psychological disorders related to the COVID-19 pandemic.

The Centers for Disease Control and Prevention (CDC) [9] also mentioned that being in the midst of the COVID-19 disease outbreak, can cause distress in society, such as fear, anxiety about a disease, and strong negative emotions in adults. In China, according to a research conducted by Qiu et al. [10] it is found that early adults experienced the highest levels of stress symptoms in response to COVID19 compared to other age groups. This is in line with Kazmi et al. [11] who conveyed in their research that during this pandemic, individuals who were in early adulthood experienced increased stress. Because in this early adulthood, these individuals will face professional life or the world of work.

In the midst of the COVID-19 pandemic, career or workrelated topic has made individuals feel anxious, especially for individuals in the early adulthood stage. Because in this stage, individuals are preparing to join the workforce, 
especially the final year students. Future career or work is an important aspect besides academic problems that concern students. In addition, during this period, final year students are also required to be independent in various ways, one of which is from a financial perspective, in order to meet their needs in the future. In the theory of career development, developed by Super [12], university or college graduates who aged 23 to 25 years, are in the career selection stage, and starting to develop career expectations. However, the presence of COVID-19 is an obstacle for final year students who are carrying out their roles in their early adulthood, such as planning their future careers. Uncertainty about the future of a career in a pandemic like this often has an impact on the quality of life of an individual, thereby causing a student to become anxious when considering their career [13].

Seeing that available job opportunities are increasingly limited and the unemployment rate is increasing, prospective workers such as final year students can experience the phenomenon of anxiety in their future career achievements. This is in line with the results of a survey conducted in the midst of this pandemic by the Strada Education Network in Anderson [14] which showed that new college graduates show increased anxiety due to the increasing number of unemployment, economic recession, potential loss of job opportunities and lower wages in their respective countries for each industry. In addition, a qualitative survey conducted on new graduates of the University of California in July 2020 show that anxiety is felt collectively by students and fresh graduates because their careers have been completely altered due to the pandemic [15]. Anxiety is one of the psychological impacts caused by the uncertainty felt after becoming a college graduate, including fears about how to get a steady job and wages, which could form future career anxiety for individuals entering the workforce. More so amidst the pandemic, increasing challenges and competition to enter the workforce have further increase anxiety felt by final year students.

Hence, the core issue in this study is, "whether stress during the COVID-19 pandemic plays a role on future career anxiety in final year students". Based on the core issue listed above, the aim of this study is to examine the role of stress during the COVID-19 pandemic on the future career anxiety of final year students. The information and results achieved in this research is hoped to be of use as a reference for further research, especially regarding stress associated with the COVID-19 pandemic and future career anxiety.

The systematic writing of this study consists of five sections. Section 1 introduction, this section contains a general description that includes background problems, problem formulation, research objectives, research benefits, and writing systematics. Section 2 theoretical study, consists of discussion regarding the theoretical basis used in each variable. Section 3 research method, consists of discussions regarding research participants, types of research, research settings and tools, research measurement tools, research procedures, processing and data analysis techniques. Section 4 results and discussion, this section discusses the description of the object of research as well as data analysis and discussion of the results of data processing. And section 5 conclusion, this chapter discusses the conclusions of the research results that have been carried out, the strengths and limitations of the research, research suggestions for overcoming these problems, and suggestions for future research.

\section{THEORETICAL STUDY}

\subsection{Stress During the COVID-19 Pandemic}

For each person, stress can be interpreted as a different condition. The general definition of stress put forward by Selye [16] states that stress is the body's non-specific response to a load on it. Stress is also defined by Lazarus and Folkman in Butler [17] that stress is a particular relationship between an individual and the environment, which is considered by the individual as a burden that exceeds its resources and is dangerous. Apart from that, in behavioral science, stress can be considered as a perceived threat that results in discomfort, anxiety, emotional tension, and difficulty in adjustment [16]. In a pandemic situation like this, anxiety-related stress responses include fear of being infected, fear of coming into contact with objects or surfaces that may be contaminated, and fear of strangers who may carry disease infections [18].

\subsection{Future Career Anxiety}

This anxiety is at the core of Freud's theory. In defining anxiety, Freud in Feist et al. [19] emphasizes that anxiety is a feeling, affective, and discomfort that is followed by physical sensations that warns the person against impending dangers. Lewis in Endler and Kocovski [20] defined anxiety as an emotional state, with the quality of fear experienced subjectively as a closely related emotion. These associated emotions are emotions that are unpleasant, negative in nature, disproportionate to the threats faced, diverted to the future, and involve real bodily disturbances. Pisarik et al. [21] defined career anxiety as an anxiety that is embedded in an individual's career problem when facing career development process. Agustin [22] also adds that anxiety in facing the future is a situation where individuals feel anxious, afraid, worried, and unconfident in their abilities, that they started to have bad thoughts about their future career.

In connection with the description above, the researchers found previous researches related to stress during the pandemic and future career anxiety in final year students. Research by Mahmud et al. [13] conducted a research on regular students from various universities in Bangladesh who are unemployed and will enter the world of work for the next 6 to 12 months. The results show that, there is a significant relationship between 'Fear of COVID-19' and future workforce career summaries, which means that due to the COVID-19 outbreak, the future workers are increasingly anxious towards their future careers. On the other hand, with depression caused by COVID-19 as a 
mediator, the indirect link between 'Fear of COVID-19' and future workforce careers is significant and results in full mediation [13]. However, the past study only examined a small part of the stress indicator, namely fear. Therefore, in this research, researchers will explain and research more comprehensively and broadly about the stress that occurs during a pandemic. In accordance with Spielberger [23] whom mentioned that stress construction can refer to negative situations or conditions that can cause an anxiety reaction as a reaction derived from stess.

Based on descriptions in theoretical concepts related to stress during the COVID-19 pandemic and future career anxiety, the researchers proposed a hypothesis in this study, that stress has a role during the COVID-19 pandemic on future career anxiety in final year students.

\section{METHODS}

This study involved 432 respondents. The participants' characteristics taken in this study are (1) final year students who will complete their studies in 2020-2021, (2) students who are actively studying (3) students who will face the job market within 6 to 12 months, and (4) students included in the 2015-2017 class. This study uses nonprobability sampling techniques.

In measuring stress during this pandemic, researchers used the COVID-19 Stress Scale (CSS) measurement tool developed by Taylor et al. [18] that has been translated into the Indonesian language. To determine the reliability and validity, the researcher tested the CSS questionnaire to 31 participants. The CSS consists of 36 statement items that are divided into five dimensions. After testing the CSS measuring instrument and conducting item analysis, items that are considered valid $(r \geq 0.2)$ will be retained, while items that are not valid will be eliminated. After eliminating $<0.2$ items, there were only 34 items left out of 36 items. Then the researchers re-tested the Cronbach Alpha reliability and validity on the overall data. Results of the reliability test from the re-test, showed that the measuring instrument had high reliability and validity above 0.2. In the dimensions of COVID Danger and Contamination of 0.865 , COVID Socioeconomic Consequences of 0.919, COVID Xenophobia of 0.901, COVID Traumatic Stress Symptoms of 0.875 , COVID Compulsive Checking of 0.873 .

Future career anxiety in this study was measured using the Career Anxiety Scale developed by Harber and Runyon [24] which has been adapted into the Indonesian language by Fatmawati [25]. This measuring instrument consists of four aspects with a total of 36 items. In order to find out the reliability and validity of this instrument, the researcher also conducted a small trial on Future Career Anxiety on 31 participants. After testing the measuring instrument and eliminating the items, the Cronbach Alpha reliability test was performed again. It was found that the measuring instrument has good reliability and the validity of the items is above 0.2 . The cognitive aspect is 0.751 , the motor aspect is 0.658 , the somatic aspect is 0.822 , the affective aspect is 0.740 .
After testing the two measuring instruments on 31 final year students and it was known that the measuring instrument had a good reliability value, the researchers prepared self-informed consent, information form, eight statements which were considered as additional data and the two measuring instruments into Google Form which are disseminated on various social media of the targeted population. To analyze the data, researchers conducted an assumption test by conducting normality and linearity test. Furthermore, in order to test the hypothesis and drawing conclusions, the researcher previously conducted a correlation test and progressed with a simple linear regression analysis with the help of the Statistical Program for Social Sciences (SPSS) version 25.00 on Windows. This was done to measure the role of stress in the COVID19 pandemic and anxiety in the future career of final year students. In additional data analysis, the researcher conducted a different test of the dependent variable and control data that had been obtained during data collection.

\section{RESULTS AND DISCUSSIONS}

Based on the test results using the Simple Linear Regression analysis shows that stress during the pandemic significantly contributes to future career anxiety, the analysis results show that the value of $F(1,430)=37,140$, $\mathrm{p}<0.05$, and R Square $\left(\mathrm{R}^{2}\right)=0.080(8 \%)$. From the results of testing the hypothesis, it can be concluded that there is a stress of the COVID-19 pandemic has a role on the future career anxiety in final year students, the stress variable during the pandemic can only explain the future career variable variables as much as $8 \%$, while the rest is influenced by other factors outside of this research.

Table 1 Simple Linear Regression Analysis

\begin{tabular}{cccc}
\hline $\begin{array}{c}\text { Independent } \\
\text { Variable }\end{array}$ & $\begin{array}{c}\text { Dependent } \\
\text { Variable }\end{array}$ & R Square & (Sig.) \\
\hline $\begin{array}{c}\text { Stress during } \\
\text { the COVID- }\end{array}$ & $\begin{array}{c}\text { Future } \\
\text { Career } \\
19 \text { pandemic }\end{array}$ & 0.080 & 0.000 \\
Anxiety & & \\
\hline
\end{tabular}

Based on the results of the overall data analysis, it shows that stress during the pandemic has a significant relationship and role to future career anxiety. From the test results of this study, it is in line with the research conducted by Mahmud et al. [13] in the context of COVID-19, which shows that there is a significant relationship between 'Fear of COVID-19' and future workforce career anxiety, which means that due to the COVID-19 outbreak, the future workers are increasingly worried about their future careers. The magnitude of the role of stress related to the COVID-19 pandemic, which is found to have a role of only $8 \%$ in this research, showed that there are other factors which students felt concerned of. The stress condition that plays more role for final year students in this pandemic is academic stress. This statement is reinforced by Muslim [26] which states that academic stress is one of the things experienced by 
students, which arises because there are too many demands and tasks that must be done in the midst of this pandemic. In addition, due to restrictions on campus activities, the stress conditions faced by students during the pandemic also include the learning model that is currently being applied throughout the world, namely the distance learning model or online learning. The sudden change in learning media from face-to-face to online learning cannot run effectively. Coupled with final year students who will complete their studies, such as preparation for job search, completing final assignments, internships and other things related to final semester assignments, are hampered by the COVID-19 pandemic. This statement is reinforced by research conducted by Livana et al. [27] which shows that "learning assignments" are a major factor causing student stress in Indonesia during the COVID-19 pandemic.

In the future career anxiety variable in this study, refers to the anxiety that is closely related to temporary or situational conditions of an individual with their environment. The changes in an individuals' environment during the pandemic, that limits the space for students to further explore their future careers, may cause students to worry about their future careers if the COVID-19 pandemic continues. This statement is in line with Carpenito's theory in Samreen and Zubair [28] which states that one of the factors that can influence anxiety is situational factors. If the environment is not well structured, it can make students easily feel threatened and have a greater tendency to experience anxiety. The small role of the independent variable (stress during the COVID19 pandemic) found in this study happened because researchers found several studies that show that career anxiety amid the COVID-19 pandemic can be influenced by several other factors. Such as the research conducted by Islam [29] found that there is a direct effect of selfreflection on career anxiety. The phenomenon of the COVID-19 pandemic, which increases the competition rate to find a job, can form career anxiety which may also be influenced by the level of self-confidence. In a study conducted by Nugroho [30] it is found that self-confidence was able to reduce student anxiety in the final year, especially the anxiety felt in facing the professional world. In addition, because the COVID-19 pandemic limits space and activities, it can hamper final year students from exploring their potential or abilities. Research by Rahmawati and Dwityanto [31] states that the lack of expertise and experience in final year students facing the field of work, would make individuals feel difficult in facing competition in the workforce, and this difficulty can cause anxiety. In connection with several internal factors that have been stated previously, there are also external factors that can influence career anxiety. Such as certainty of being accepted by the company, certainty of sufficient wages, years of service, colleagues and employers [32].

The results of measuring the variables of future career anxiety in terms of gender show that there are significant differences in male and female subjects, and female subjects have a higher experience of anxiety about future careers than male subjects. The results supported by Maryam [33] also stated that gender is one of the factors that can affect the level of individual anxiety. In her study, it is found that women are more at risk of experiencing anxiety than men, due to differences in structure and compounds in the brain and hormones.

\section{CONCLUSION}

Based on the results of measurements in this study, it can be concluded from the results of the study that there is a significant role of stress during the pandemic COVID-19 on future career anxiety in final year students. Through this research, future researchers who want to carry out research on stress during the pandemic COVID-19 and future career anxiety can consider other factors outside of this research. There are some factors which are likely to cause future career anxiety in final year students such as aspects related to academic conditions, personality traits in the Big Five Personality according to Costa and McCrae, psychological well-being, perfectionism, optimism, and some of them and could also be applied as a moderator variable between stress towards career anxiety.

Furthermore, the researchers would like to give a few suggestions, in which students should be able to find and sort out the latest valid and credible facts in order to reduce the stress caused by this pandemic. In addition, stress avoidance could also be done by limiting the media that spreads information related to pandemic COVID-19 that increases fear and anxiety. Students are expected to also be able to carry out daily activities even from home, take part in online counseling services to seek guidance if needed, make good time management and meditate. Furthermore, regarding career anxiety, the researchers suggest that students who will enter the workforce in the near future can better utilize information on the internet to compile and explore more about career planning. Students are also expected to be able to take advantage of supporting facilities such as taking classes or online seminars to increase knowledge and experience about their field or career of interest, and using social media to expand their relations.

\section{ACKNOWLEDGMENT}

This research was supported by the Faculty of Psychology, Universitas Tarumanagara, Jakarta, Indonesia.

\section{REFERENCES}

[1] Maarefvand, M., Hosseinzadeh, S., Farmani, O., Farahani, A. S., \& Khubchandani, J. (2020). Coronavirus Outbreak and Stress in Iranians. International Journal of Environmental Research and Public Health. 17(4441), DOI: 10.3390/ijerph 17124441. 
[2] Jabri, A., Kalra, A., Kumar, A., Alameh, A., Adroja, S., Bashir, H., Nowacki, A. S., Shah, R., Khubber, S., Kanaa'N, A., Hedrick, D. P., Sleik, K. M., Mehta, N., Chung, M. K., Khot, U. N., Kapadia, S. R., Puri, R., \& Reed, G. W. (2020). Incidence of stress cardiomyopathy during the coronavirus disease 2019 pandemic. Jama Network Open. 3(7), 1-7. DOI: 10.1001/jamanetworkopen.2020.14780

[3] IASC. (2020). Catatan tentang aspek kesehatan jiwa dan psikososial wabah COVID-19 versi 1.0. InterAgency Standing Commite, Reference group for Mental Health and Psychological Support in Emergency Settings.

[4] Yuwono, S. D. (2020). Profil kondisi stres di masa pandemi COVID-19 sebagai dasar intervensi dalam praktek mikrokonseling. Ristekdik: Jurnal Bimbingan dan Konseling, 5(1), 132-138.

[5] Liu, D., Ren, Y., Yan, F., Li, Y., Xu, X., Yu, X., Qu, W., Wang, Z., Tian, B., Yang, F., Yao, Y., Tan, Y., Jiang, R., \& Tan, S. (2020) Psychological Impact and Predisposing Factors of the Coronavirus Disease 2019 (COVID-19) Pandemic on General Public in China. Retrieved from http://dx.doi.org/10.2139/ssrn.3551415

[6] American Psychological Association. (2020). Keeping Your Distance to Stay Safe. Retrieved from https://www.apa.org/practice/programs/dmhi/researchinformation/socialdistancing

[7] Sood, S. (2020). Psychological effects of the Coronavirusdisease-2019 pandemic. RHIME. 2020; 7: 23-6.

[8] Perhimpunan Dokter Spesialis Kedokteran Jiwa Indonesia (PDSKJI). (2020). Masalah psikologis terkait pandemi COVID-19 di Indonesia.

[9] Centers for Disease Control and Prevention. (2020). Mental health and coping during COVID-19.

[10] Qiu, J., Shen, B., Zhao, M., Wang, Z., Xie, B., \& $\mathrm{Xu}$, Y. (2020). A nationwide survey of psychological distress among Chinese people in the COVID-19 epidemic: implications and policy recommendations. General psychiatry, 33(2). doi: 10.1136/gpsych-2020100213

[11] Kazmi S. S. H., Hasan K., Talib S., Saxena S., (2020). COVID-19 and Lockdown: A Study on the Impact on Mental Health. SSRN Electron J.

[12] Super, D. E. (1980). A life-span, life-space approach to career development. Journal of Vocational
Behavior, 16(3), 282- $298 . \quad$ doi:10.1016/00018791(80)90056-1

[13] Mahmud, M. S., Talukder, M. U., \& Rahman, S. M. (2020). Does 'Fear of COVID-19' trigger future career anxiety? An empirical investigation considering depression from COVID-19 as a mediator. The International Journal of Social Psychiatry. 00(0), DOI: 10.1177/0020764020935488

[14] Anderson, G. (2020). A generation defined by the pandemic. Inside Higher Ed. Retrieved from https://www.insidehighered.com/news/2020/10/15/stud ents-continue-be-stressed-about-college-their-futures

[15] Morris. L. (2020) Spring Quarter Snapshot: Interviews Focus on How the Coronavirus is Changing Work. UCDavis. Retrieved from https://www.ucdavis edu/spring-snapshots/news/interviews-focus-howcoronavirus-changing-work

[16] Selye, H. (1975). Confusion and Controversy in the Stress Field. Journal of Human Stress, 1(2), 37-44. DOI: 10.1080/0097840x.1975.9940406

[17] Butler, G. (1993). Definitions of stress. Occasional paper (Royal College of General Practitioners), (61), 1.

[18] Taylor, S., Landry, C., Paluszek, M., Fergus, T. A., McKay, D., \& Asmundson, G. J. (2020). Development and initial validation of the COVID Stress Scales. Journal of Anxiety Disorders, 102232. DOI: 10.1016/ j.janxdis.2020. 102232

[19] Feist, J., \& Feist. G J., \& Roberts T. A. (2013) Theories of personality: Eighth Edition. McGraw-Hill.

[20] Endler, N. S., \& Kocovski. N. L. (2001). State and trait anxiety revisited. Journal of Anxiety Disorders. 15(3), 232-233. DOI:10.1016/s0887-6185(01)00060-3

[21] Pisarik, C. T., Rowell, P. C., \& Thompson, L. K. (2017). A Phenomenological Study of Career Anxiety Among College Students. The Career Development Quarterly, 65(4), 339-352. DOI:10.1002/cdq.12112

[22] Agustin, N. (2019). Pengaruh terapi shalat dhuha dalam mengurangi kecemasan karir masa depan siswa di SMA Muhammadiyah 8 Gresik. [Skripsi dipublikasikan]. Universitas Inslam Negeri Sunan Ampel Surabaya.

[23] Spielberger, C. D. (1966). Theory and research on anxiety. In: Anxiety and behavior. Spielberger, C. D. (Ed.) Academic Press, New York. 
[24] Harber, A., \& Runyon, R. P. (1984). Psychology of adjustment. Illinois: The Dorsey Press.

[25] Fatmawati. (2016). Pengaruh dukungan sosial terhadap kecemasan karir siswa kelas XI akuntansi di SMK Negeri 1 Bantul. [Skripsi dipublikasikan]. Universitas Negeri Yogyakarta.

[26] Muslim, M. (2020). Manajemen stress pada masa pandemi COVID-19. Jurnal Manajemen Bisnis. 23(2).

[27] Livana, P. H., Mubin, M. F., \& Basthomi, Y. (2020). " Learning Task" Attributable to Students' Stress During the Pandemic Covid-19. Jurnal Ilmu Keperawatan Jiwa, 3(2), 203-208. http://dx.doi.org/10. 32584/jikj.v3i2. 590

[28] Samreen, H., \& Zubair, A. (2013). Locus of control and death anxiety among police personnel. Pakistan Journal of Psychological Research, 28(2), 261.

[29] Islam M. A., Barna, S. D., Raihan, G., Khan, M. N. A., \& Hossain, M. (2020). Depression and anxiety among university students during the COVID-19 pandemic in Bangladesh: A web-based cross-sectional survey. PLOS ONE, 15(8). E0238162. https://doi.org/ 10.1371/journal. pone. 0238162

[30] Nugroho, T.F.A. (2010). Hubungan antara kepercayaan diri dengan kecemasan dalam menghadapi dunia kerja pada mahasiswa semester akhir di Fakultas Psikologi Universitas Sanata Dharma Yogyakarta. [Skripsi dipublikasikan]. Universitas Sanata Dharma Yogyakarta.

[31] Rahmawati, N.S., \& Dwityanto, A. (2017). Hubungan antara efikasi diri dengan kecemasan menghadapi dunia kerja pada siswa smk muhammadiyah karanganyar. [Skripsi dipublikasikan]. Universitas Muhammadiyah Surakarta.

[32] Alkhathami, S., Kaviani, H., \& Emma, S. (2014). Social anxiety among adolescents and its relation to quality of life. Eur Proc Soc Behav Sci, 218, 228.

[33] Vellyana, D., Lestari, A., \& Rahmawati, A. (2017). Faktor-faktor yang berhubungan dengan tingkat kecemasan pada pasien preoperative di RS Mitra Husada Pringsewu. Jurnal Kesehatan, 8(1), 108-113. 